\title{
Internet's Influence On The Marketing Activities Of South African Companies
}

Kirsty-Lee Sharp, North-West University, South Africa

Ayesha Lian Bevan-Dye, North-West University, South Africa

Natasha de Klerk, North-West University, South Africa

\begin{abstract}
Although research studies regarding the Internet's impact on marketing conducted in the past in different countries and at different times produced quite similar trends in responses, advances in Internet technologies and the increased Internet usage necessitated reinvestigating marketers' perceptions as to the changes in marketing practices brought about by the Internet. This study sought to determine the South African marketing practitioners' perceptions of the Internet's influence on the practice of marketing in 2011 and compare these perceptions with those of marketers in Australia 2001 and Iran 2005.
\end{abstract}

A cross-industry survey of the marketing practitioners at the top 100 companies listed on the Johannesburg Stock Exchange in South Africa was conducted by means of a self-administered questionnaire. Questionnaires were sent via e-mail to those marketing practitioners from whom telephonic permission had been obtained.

The findings indicate that South African marketers perceive the Internet to have changed the way companies conceptualise their marketing activities, define their markets, and create value. This study contributes to the practice of marketing by outlining the potential uses of the Internet in marketing and indicating trends across three countries and time periods.

Keywords: Internet; Marketing Practice; South Africa

\section{INTRODUCTION}

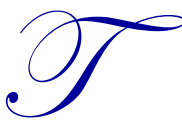

he Internet, Internet technologies and Internet services, particularly the Web, are widely acknowledged to have had and to continue to have a considerable influence on the practice of marketing (Morris et al., 1997; Leong et al., 2003; Ghazisaeedi et al., 2007; Bevan-Dye \& Venter,

2008). The Internet introduces new dimensions to traditional marketing as well as a different dimension altogether (Schiffman et al., 2010:32). According to Bevan-Dye and Venter (2008), the Internet has not only resulted in major changes in the marketing environment but also presents as an important tool for significantly enhancing the execution of key marketing activities.

Leong et al. (2002) indicate that for a short time after the so-called 'dot.com crash', many companies had a negative view of the Internet's capabilities and impact on marketing activities, but that this view began to change between 2001 and 2003. Boateng et al. (2008) propose that the use of the Internet and other related information and communication technologies to conduct business activities and transactions is growing in the private, public and non-profit sectors in both developed and developing countries.

Martin and Matlay (2003) assert that the Internet is useful for companies' marketing activities all around the world given its marketing efficiency and convenience from both a marketer and customer's point of view. Morris et al. (1997) and Leong et al. (2003) contend that many companies have seen how the Internet affects their marketing activities and that they choose to use it on a larger scale because it results in their customers being completely involved in the process while interacting on the Web. 
While more recent studies on the influence of the Internet on the marketing activities of organisations have been conducted in Australia (Leong et al., 2003) and Iran (Ghazisaeedi et al., 2007), there has been a paucity of research on this topic in the South African market since the study conducted by Morris et al. (1997). Given the advances in Internet technologies and the increase in Internet usage since the late 1990s, there was a need to reinvestigate South African marketers' perceptions of the changes in marketing practices brought about by the Internet. This is especially true in light of the 2000 dot.com crash and South Africa's ongoing digital divide (Jacobs $\&$ Sewry, 2009). This study seeks to address this gap in the literature by replicating the study conducted by Morris $e t$ al. (1997) and comparing South African marketers' perceptions of the Internet's influence on marketing practices with those in Australia and Iran.

\section{SOUTH AFRICAN INTERNET USAGE AND PENETRATION LEVELS}

In comparison to Australia's December 2011 Internet penetration level of the population of $89.8 \%$ and Iran's penetration level of 46.9\%, South Africa's level stands at a mere 13.9\% (Internet World Stats, 2012). However, while there are only about 6 million desktop Internet users in South Africa, there are an estimated 32 million Internet-enabled mobile devices, of which over 14 million actively utilise mobile Web services (Maake, 2012).

While the Internet economy is predicted to contribute R103 billion (2.5\%) to South Africa's GDP figure in 2016, up from R51 billion in 2010 (Masote, 2012), its average growth rate of $12.6 \%$ lags behind that of other comparable developing economies that average approximately 17.8\% (Mawson, 2012). At the end of 2011, South Africa had in excess of 1,000 retail portals. This, coupled with a growing number of Internet users and a surge in online social media usage, will drive South Africa's Internet economy (Tubbs, 2012). Additional factors essential to a robust Internet economy in South Africa include increased broadband penetration and a decrease in data costs (Masote, 2012).

\section{WORLD WIDE WEB MARKETING MODEL}

Morris et al. (1997) developed the World Wide Web marketing model. This model is based on the premise that the ways in which companies define their markets and the way in which they conceptualise their marketing activities influences whether or not they will adopt the Web as a marketing tool. The way in which companies may change their marketing activities is referred to as changing the conceptualisation of the marketing activity and through targeting new markets, both locally and internationally, improving segmentation and eliminating less profitable customers or segments, a change in market definition will be made possible.

In the World Wide Web Marketing Model, illustrated in Figure 1, the adoption of the Web is the link between the marketing function and the creation of value. The arrows illustrate the gaps between these two interrelated aspects. As these gaps are filled and they become smaller, the link between the marketing function and the value created becomes stronger (Ghazisaeedi et al., 2007).

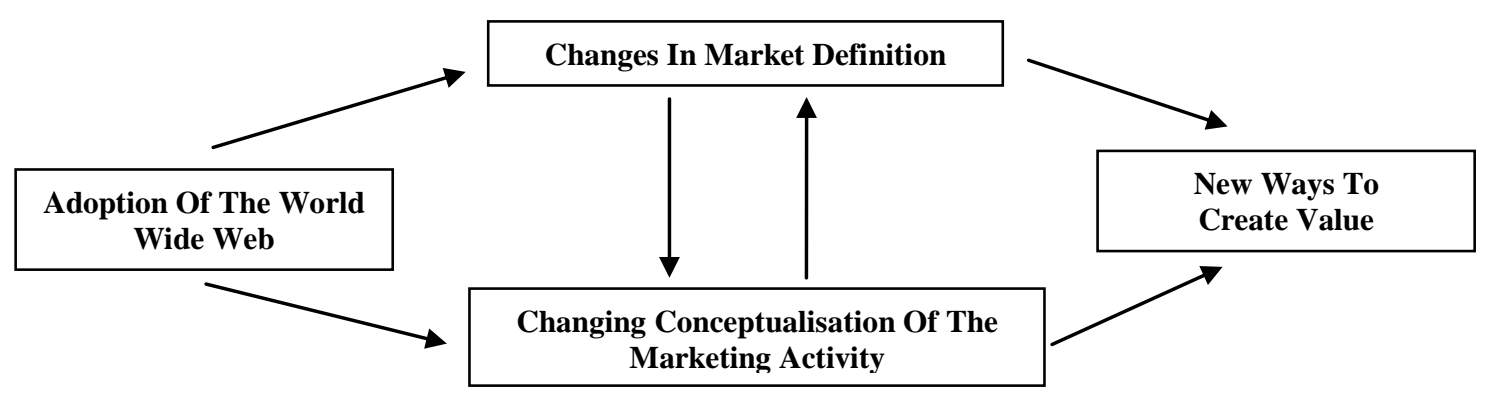

Figure 1: World Wide Web Marketing Model

Source: Morris et al. (1997) 
According to Morris et al. (1997), the Internet and a well-developed company website will influence the conceptualisation of the marketing activities of companies. They point out that the Internet enhances corporate visibility, helps develop brand recognition, effectively communicates product and/or service information, aids in establishing two-way interactive relationships with customers, improves the job of selling, and enhances the capabilities of companies to bring new products to market. Leong et al. (2003) add that the Internet has a significant influence on promotional strategies and the way in which products are marketed. Ghazisaeedi et al. (2007) suggest that, in addition to the permitting of online payments in the future, the Internet will provide a medium to combine online activities such as games, competitions and news bytes to assist with the building and maintaining of customer relationships.

As such, the Internet provides a new medium through which the marketing mix dimensions may be facilitated by providing an additional marketing channel (Eid \& Trueman, 2002; Florenthal \& Shoham, 2010).

Landberg (2003) suggests that the marketplace is concerned with the physical value chain, whereas the marketspace is the realm of the virtual value chain, and when companies adopt the marketspace, it influences the definition of their markets. Unlike Leong et al. (2003), who indicate that the Internet would not, at least for the time being, be used aggressively for expanding target markets, Morris et al. (1997) highlight that the Internet's influence on companies' market definitions is prominent with regard to expanding the size of target markets, targeting customers globally and adding new segments to already targeted markets. Ghazisaeedi et al. (2007) add that the Internet assists companies in targeting new customers in completely new market segments. For this reason, marketers must engage in marketing research to determine if and how currently served markets are accessing the Internet. If usage rates deem this a viable means of targeting customers, marketers must determine appropriate ways of adapting content to typically used devices amongst target markets, such as desktops/laptops/mobile phones/tablets.

Morris et al. (1997) assert that both a change in market definition and a change in the conceptualisation of marketing activities are linked to the ability of companies to create value in new ways. Along with Ghazisaeedi et al. (2007), they propose that the use of the Internet allows companies to obtain vital information concerning their customers' wants and expectations, develop new products faster, keep customers more informed, and enable customers to make better-informed buying decisions. Morris et al. (1997) and Leong et al. (2003) add that the Internet provides companies with a means to serve their customers more quickly and Morris et al. (1997) suggest that it makes it easier for customers to buy.

\section{METHODOLOGY}

\section{Sample}

The e-mail survey method using the attachment mode was used to gather the required data. The target population was delineated as marketing directors or marketing managers employed within the marketing departments of South African companies. A non-probability judgement sample of the 100 top South African companies, ranked according to turnover, listed on the Johannesburg Stock exchanges as published by the Financial Mail (2009), was taken in April 2011. This sample represents 30 of the 39 industry sectors of South Africa. Each of these 100 companies was contacted telephonically to obtain permission to forward the questionnaire to the relevant marketing practitioners as well as to obtain their e-mail addresses.

\section{Research Instrument}

The scale developed by Morris et al. (1997) was employed to measure South African marketing practitioners' perceptions of the Internet's influence on marketing on the dimensions of changes in the conceptualisation of marketing activities (11 items), changes in market definition (8 items) and value creation (12 items). Responses to the scale were measured on a five-point Likert scale ranging from $1=$ to a very little extent to 5 $=$ to a very great extent. The self-administered questionnaire included a section requesting demographic information and a cover letter explaining the purpose of the study and requesting participation. 
The questionnaire was piloted on a convenience sample of 30 South African companies that did not form part of the main sample in order to determine the reliability of the scale. The scale returned an acceptable Cronbach alpha of 0.971 for the overall scale, with Cronbach alphas ranging from 0.928 to 0.933 for the individual dimensions.

\section{RESULTS}

Of the 100 companies that were e-mailed questionnaires, 74 responses were received, with 67 companies providing one response each, two companies providing two responses each, and one company providing three responses. Responses were received from 20 of South Africa's 39 industry sectors. Of the respondents, 27 percent failed to indicate into which industry sector their company fell and are classified here as 'other'. The sectors, together with the percentage respondents within each sector, are listed in Table 1.

Table 1: Industry Sectors Represented by Respondents

\begin{tabular}{|l|l|c|}
\hline \multicolumn{1}{|c|}{ Sector } & Percentage Of Respondents (\%) \\
\hline 1 & Construction and Building Materials & 11 \\
\hline 2 & Media and Entertainment & 3 \\
\hline 3 & Mining: Platinum & 1 \\
\hline 4 & Mining: Gold & 7 \\
\hline 5 & Mining: Other Mineral Extractors and Mines & 3 \\
\hline 6 & Investments & 5 \\
\hline 7 & Insurance & 3 \\
\hline 8 & Electronic and Electrical Equipment & 1 \\
\hline 9 & Household goods and textiles & 1 \\
\hline 10 & Chemicals & 5 \\
\hline 11 & Transport & 3 \\
\hline 12 & General Retailers & 7 \\
\hline 13 & Food Producers and Processors & 1 \\
\hline 14 & Health & 1 \\
\hline 15 & Life Assurance & 1 \\
\hline 16 & Steel and other metals & 3 \\
\hline 17 & Software and Computer Services & 4.5 \\
\hline 18 & Automobiles and Parts & 4.5 \\
\hline 19 & Information Technology: Hardware & 5 \\
\hline 20 & Engineering and Machinery & 27 \\
\hline 21 & Other & \\
\hline
\end{tabular}

In the main study, a Cronbach alpha of 0.85 was computed on the conceptualisation of marketing activities dimension, 0.87 on the market definition dimension, and 0.90 on the value creation dimension. In comparison to other studies that employed this scale, Ghazisaeedi et al. (2007) reports reliability coefficients of 0.85 for the conceptualisation of the marketing activities dimension and 0.87 for both the market definition dimension and the value creation dimension, and Leong et al. (2001) and Morris et al. (1997) indicate reliability alphas exceeding 0.87 and 0.88 , respectively. 
Table 2 ranks, from highest to lowest mean, South African practitioners' perceptions on the Internet's influence on the conceptualising marketing activities, market definition and value creation, as well as the items within each of these dimensions.

Table 2: Changes in the Conceptualisation of Marketing Activities, Market Definition and Value Creation According to Their Ranking

\begin{tabular}{|c|c|c|c|}
\hline \\
\hline Item & Rank & Mean & Standard Deviation \\
\hline Items on change in the conceptualisation of marketing activities & 1 & 3.52 & 1.17 \\
\hline An effective channel for communicating product/service information & 1 & 4.19 & 0.86 \\
\hline Change the way in which products/services are marketed & 3 & 3.77 & 1.21 \\
\hline Enable two-way interactive relationships with customers & 4 & 3.74 & 1.24 \\
\hline Influence promotional strategies & 6 & 3.59 & 1.16 \\
\hline Enhance capabilities to bring new products to the market & 5 & 3.60 & 1.33 \\
\hline Provide an effective vehicle for improving market segmentation & 8 & 3.47 & 1.14 \\
\hline Permit online payments & 2 & 3.97 & 1.39 \\
\hline Permit involvement with customers earlier in the buying process & 7 & 3.56 & 1.17 \\
\hline Do a better job of selling & 10 & 2.79 & 1.12 \\
\hline Permit a reduced need for middlemen & 9 & 3.04 & 1.23 \\
\hline Influence the way in which products are priced & 11 & 2.64 & 1.24 \\
\hline Items on changes in market definitions & 3 & 3.16 & 1.23 \\
\hline Expand the size of a targeted market & 6 & 3.09 & 1.26 \\
\hline Target new customers in currently served markets & 5 & 3.11 & 1.18 \\
\hline Target new customers in totally new market segments & 3 & 3.26 & 1.27 \\
\hline Target new customers globally & 2 & 3.46 & 1.36 \\
\hline Add new segments to targeted markets & 7 & 2.96 & 1.25 \\
\hline Define markets more precisely & 4 & 3.14 & 1.20 \\
\hline Provide a podium to compete more effectively globally & 1 & 3.65 & 1.25 \\
\hline Eliminate less profitable customers or market segments & 8 & 2.48 & 1.11 \\
\hline Items on value creation & 2 & 3.35 & 1.18 \\
\hline Improve company abilities to keep customers more informed & 1 & 4.26 & 0.85 \\
\hline Enable companies to serve customers more quickly & 2 & 3.90 & 1.04 \\
\hline Enable customers to make more informed buying decisions & 3 & 3.90 & 0.97 \\
\hline Do a better job of researching customer needs & 4 & 3.42 & 1.03 \\
\hline Make it easier for customers to buy & 5 & 3.42 & 1.22 \\
\hline Provide a better way to identify unmet customer needs & 8 & 3.10 & 1.02 \\
\hline Promote better customisation of products and services & 9 & 3.07 & 1.18 \\
\hline Provide better understanding of the customer's buying process & 10 & 2.96 & 1.14 \\
\hline Lower marketing costs & 6 & 3.17 & 1.23 \\
\hline Provide a way for companies to price more accurately & 11 & 2.76 & 1.17 \\
\hline Improve new product development & 9 & 3.07 & 1.11 \\
\hline Assist in developing new products faster & 7 & 3.14 & 1.13 \\
\hline
\end{tabular}

Five-point scale, where $1=$ to a very little extent to $5=$ to a very great extent

Means above 3 were computed for 25 of the 31 items, indicating that South African marketers perceive the Internet to have had an influence on most aspects of marketing within their companies. As is evident from Table 2, South African marketing practitioners perceive the Internet to have had the strongest influence on changes in the conceptualisation of marketing activities (Mean=3.52), followed by its influence on changes in value creation (Mean=3.35). The Internet's influence on changes in market definition was ranked lowest (Mean=3.16).

In terms of changing the conceptualisation of marketing activities, the highest mean was recorded on the Internet being an effective channel for communicating product/service information (Mean=4.19) and the lowest means on it doing a better job selling $(m e a n=2.79)$, followed by its influence on the way in which products are priced (Mean=2.64). The Internet's influence on competing more effectively globally (Mean=3.65) and targeting new customers globally (Mean=3.46) were ranked in first and second place under the Internet's influence on changes in market definition, while its influence on eliminating less profitable customers/market segments (Mean=2.48) and add new segments to targeted markets (Mean=2.96) were ranked lowest. Concerning the value 
creation dimension, the Internet's influence on keeping customers informed (Mean=4.26) has ranked first, while its influence on understanding customers' buying processes (Mean=2.96) and pricing more accurately (Mean=2.76) were ranked lowest.

In order to determine how South African practitioners' perceptions in 2011 compare to those in other countries, the results of this study were compared with the results of previous studies conducted in Australia in 2001 (Leong et al., 2003) and Iran in 2005 (Ghazisaeedi et al., 2007).

Table 3 reports the means recorded on the items pertaining to the Internet's influence on the conceptualisation of marketing activities, market definition and value creation for the three studies order to highlight similarities and difference.

Table 3: Internet's Influence on Marketing Across Three Countries

\begin{tabular}{|c|c|c|c|}
\hline & \multicolumn{3}{|c|}{ Means } \\
\hline & $\begin{array}{c}\text { Australia } \\
(2001)\end{array}$ & $\begin{array}{c}\text { Iran } \\
(2005)\end{array}$ & $\begin{array}{c}\text { South Africa } \\
(2011)\end{array}$ \\
\hline Items On Change In The Conceptualisation Of Marketing Activities & 3.20 & 2.97 & 3.49 \\
\hline An effective channel for communicating product/service information & 4.18 & 3.51 & 4.19 \\
\hline Change the way in which products/services are marketed & 3.84 & 2.80 & 3.77 \\
\hline Enable two-way interactive relationships with customers & 3.67 & 3.14 & 3.74 \\
\hline Influence promotional strategies & 3.54 & 3.05 & 3.59 \\
\hline Enhance capabilities to bring new products to the market & 3.15 & 3.1 & 3.60 \\
\hline Provide an effective vehicle for improving market segmentation & 3.13 & 2.93 & 3.47 \\
\hline Permit online payments & 3.08 & 3.11 & 3.97 \\
\hline Permit involvement with customers earlier in the buying process & 2.98 & 3.00 & 3.56 \\
\hline Do a better job of selling & 2.97 & 3.01 & 2.79 \\
\hline Permit a reduced need for middlemen & 2.55 & 2.96 & 3.04 \\
\hline Influence the way in which products are priced & 2.16 & 2.09 & 2.64 \\
\hline Items On Changes In Market Definitions & 2.85 & 2.98 & 3.14 \\
\hline Expand the size of a targeted market & 3.19 & 3.04 & 3.09 \\
\hline Target new customers in currently served markets & 3.17 & 3.15 & 3.11 \\
\hline Target new customers in totally new market segments & 3.11 & 3.19 & 3.26 \\
\hline Target new customers globally & 2.91 & 3.24 & 3.46 \\
\hline Add new segments to targeted markets & 2.85 & 3.18 & 2.96 \\
\hline Define markets more precisely & 2.65 & 2.84 & 3.14 \\
\hline Provide a podium to compete more effectively globally & 2.64 & 2.92 & 3.65 \\
\hline Eliminate less profitable customers or market segments & 2.29 & 2.26 & 2.48 \\
\hline Items On Value Creation & 3.04 & 3.09 & 3.35 \\
\hline Improve company abilities to keep customers more informed & 4.11 & 3.7 & 4.26 \\
\hline Enable companies to serve customers more quickly & 3.61 & 3.28 & 3.90 \\
\hline Enable customers to make more informed buying decisions & 3.61 & 3.54 & 3.90 \\
\hline Do a better job of researching customer needs & 3.31 & 3.2 & 3.42 \\
\hline Make it easier for customers to buy & 3.23 & 3.04 & 3.42 \\
\hline Provide a better way to identify unmet customer needs & 2.88 & 2.91 & 3.10 \\
\hline Promote better customisation of products and services & 2.84 & 2.84 & 3.07 \\
\hline Provide better understanding of the customer's buying process & 2.77 & 2.81 & 2.96 \\
\hline Lower marketing costs & 2.72 & 2.93 & 3.17 \\
\hline Provide a way for companies to price more accurately & 2.50 & 2.35 & 2.76 \\
\hline Improve new product development & 2.48 & 3.17 & 3.07 \\
\hline Assist in developing new products faster & 2.47 & 3.33 & 3.14 \\
\hline
\end{tabular}

Five-point scale, where $1=$ to a very little extent to $5=$ to a very great extent

The results in Table 3 suggest that, in comparison to both Australian and Iranian marketers, South African marketers rated the Internet to have had a greater influence on 24 of the 31 items. The top two scored items across the three studies were being an effective channel for communicating product/service information and improving the company's ability to keep customers informed. The lowest scored items across the study included influencing the way products are priced, eliminating less profitable segments and pricing more accurately. 
A t-test for independent samples was conducted to compute whether there was a statistically significant difference between the results of the three studies. The significance level was set at the conventional 5 percent; that is, $a=0.05$. Table 4 reports on the findings.

Table 4: Comparing South Africa 2011 with Australia 2001 and Iran 2005

\begin{tabular}{|c|c|c|}
\hline & \multicolumn{2}{|c|}{ t-values } \\
\hline & $\begin{array}{c}\text { South Africa } \\
\text { (2011) versus } \\
\text { Australia (2001) }\end{array}$ & $\begin{array}{l}\text { South Africa } \\
\text { (2011) versus } \\
\text { Iran (2005) } \\
\end{array}$ \\
\hline \multicolumn{3}{|l|}{ Marketing Activities } \\
\hline Q1: An effective channel for communicating product/service information & 0.05 & $4.88^{*}$ \\
\hline Q2: Change the way in which products/services are marketed & -0.10 & $6.15^{*}$ \\
\hline Q3: Enable two-way interactive relationships with customers & $3.89 *$ & $7.21 *$ \\
\hline Q4: Influence promotional strategies & 0.28 & $3.22 *$ \\
\hline Q5: Enhance capabilities to bring new products to the market & $2.33 *$ & $2.64 *$ \\
\hline Q6: Provide an effective vehicle for improving market segmentation & 1.80 & $3.08^{*}$ \\
\hline Q7: Permit online payments & $4.42 *$ & $4.28^{*}$ \\
\hline Q8: Permit involvement with customers earlier in the buying process & $3.39 *$ & $3.28 *$ \\
\hline Q9: Do a better job of selling & -1.23 & -1.48 \\
\hline Q10: Permit a reduced need for middlemen & $2.77 *$ & 0.39 \\
\hline Q11: Influence the way in which products are priced & $2.79 *$ & $3.17 *$ \\
\hline \multicolumn{3}{|l|}{ Market Definitions } \\
\hline Q12: Expand the size of a targeted market & -0.42 & 0.44 \\
\hline Q13: Target new customers in currently served markets & -0.25 & -0.13 \\
\hline Q14: Target new customers in totally new market segments & 1.00 & 0.55 \\
\hline Q15: Target new customers globally & $2.90 *$ & 1.20 \\
\hline Q16: Add new segments to targeted markets & 0.87 & -1.06 \\
\hline Q17: Define markets more precisely & $3.17^{*}$ & 2.05 \\
\hline Q18: Provide a podium to compete more effectively globally & $5.60^{*}$ & $4.00^{*}$ \\
\hline Q19: Eliminate less profitable customers or market segments & 1.11 & 1.38 \\
\hline \multicolumn{3}{|l|}{ Value Creation } \\
\hline Q20: Improve company abilities to keep customers more informed & 1.31 & $4.34 *$ \\
\hline Q21: Enable companies to serve customers more quickly & 1.72 & $3.81^{*}$ \\
\hline Q22: Enable customers to make more informed buying decisions & 1.91 & $2.38^{*}$ \\
\hline Q23: Do a better job of researching customer needs & 0.75 & 1.50 \\
\hline Q24: Make it easier for customers to buy & 1.05 & $2.13^{*}$ \\
\hline Q25: Provide a better way to identify unmet customer needs & 1.38 & 1.16 \\
\hline Q26: Promote better customisation of products and services & 1.37 & 1.37 \\
\hline Q27: Provide better understanding of the customer's buying process & 1.27 & 1.08 \\
\hline Q28:Lower marketing costs & $2.55^{*}$ & 1.44 \\
\hline Q29: Provide a way for companies to price more accurately & 1.73 & $2.72 *$ \\
\hline Q30: Improve new product development & $3.77 *$ & -0.53 \\
\hline Q31: Assist in developing new products faster & $4.23 *$ & -1.06 \\
\hline
\end{tabular}

*Statistically significant at $\mathrm{p}<0.05$

As indicated in Table 4, in comparing the findings of the 2011 South African study with those of the 2001 Australian study, a statistically significant difference occurred on 12 items. On the conceptualisation of marketing activities dimension, a statistically significant difference was computed on six items. Compared to Australian marketers, South African marketers perceive the Internet to have a statistically significant greater influence on:

- $\quad$ enabling two-way interactive relationships with customers $(\mathrm{p}=0.000<0.05)$

- $\quad$ enhancing capabilities to bring new products to the market $(\mathrm{p}=0.027<0.05)$

- $\quad$ permitting online payments $(\mathrm{p}=0.000<0.05)$

- $\quad$ permitting involvement with customers earlier in the buying process $(\mathrm{p}=0.001<0.05)$

- $\quad$ reducing the need for middlemen $(\mathrm{p}=0.009<0.05)$

- $\quad$ influencing the way products are priced $(\mathrm{p}=0.008<0.05)$ 
On the dimension of market definition, a statistically significant difference was computed on three items. In comparison to Australian marketers, South African marketers perceive the Internet to have a statistically significant greater influence on:

- $\quad$ targeting new customers globally $(\mathrm{p}=0.006<0.05)$

- $\quad$ defining markets more precisely $(\mathrm{p}=0.003<0.05)$

- $\quad$ providing a podium to compete more effectively globally $(\mathrm{p}=0.000<0.05)$

On the value creation dimension, there is a statistically significant difference on three items. Compared to Australian marketers, South African marketers perceive the Internet to have a statistically significant greater influence on:

- $\quad$ lowering marketing costs $(\mathrm{p}=0.016<0.05)$

- $\quad$ improving new product development $(\mathrm{p}=0.000<0.05)$

- $\quad$ developing new products faster $(\mathrm{p}=0.000<0.05)$

The comparison between the 2011 South African study and the 2005 Iran study yielded a statistically significant difference on 16 items. On the dimension of conceptualisation of marketing activities, a statistically significant difference was computed on nine of the 11 items. In comparison to Iranian marketers, South African marketers perceive the Internet to have a statistically significant greater influence on:

- $\quad$ being an effective channel for communicating product/service information $(\mathrm{p}=0.000<0.05)$

- $\quad$ changing the way products/services are marketed $(\mathrm{p}=0.000<0.05)$

- $\quad$ enabling two-way interactive relationships with customers $(\mathrm{p}=0.000<0.05)$

- $\quad$ influencing promotional strategies $(\mathrm{p}=0.002<0.05)$

- $\quad$ enhancing capabilities to bring new products to the market $(\mathrm{p}=0.012<0.05)$

- $\quad$ providing an effective vehicle for improving market segmentation $(\mathrm{p}=0.003<0.05)$

- $\quad$ permitting online payment $(\mathrm{p}=0.000<0.05)$

- $\quad$ permitting involvement with customers earlier in the buying process $(\mathrm{p}=0.002<0.05)$

- $\quad$ influencing the way in which products are priced $(\mathrm{p}=0.003<0.05)$

On the dimension of market definition, a statistically significant difference was computed on one item. In comparison to Iranian marketers, South African marketers perceive the Internet to have a statistically significant greater influence on:

- $\quad$ providing a podium to compete more effectively globally $(\mathrm{p}=0.000<0.05)$

On the value creation dimension, a statistically significant difference was computed on five items. In comparison to Iranian marketers, South African marketers perceive the Internet to have had a statistically significant greater influence on:

- $\quad$ improving abilities to keep customers informed $(\mathrm{p}=0.000<0.05)$

- $\quad$ enabling companies to serve customers more quickly $(\mathrm{p}=0.000<0.05)$

- $\quad$ enabling customers to make more informed buying decisions $(\mathrm{p}=0.000<0.05)$

- $\quad$ making it easier for customers to buy ( $\mathrm{p}=0.024<0.05)$

- $\quad$ providing a way for companies to price more accurately $(\mathrm{p}=0.010<0.05)$

This suggests that South African marketers perceive the Internet as having had a greater influence on marketing compared to those who participated in the Australian and Iranian studies. 


\section{DISCUSSION}

The purpose of this study was to measure South African marketers' perceptions in 2011 of the Internet's influence on the practice of marketing. The findings suggest that South African marketers are of the opinion that Internet technologies have changed the way in which markets are defined, value is created and, most particularly, the way in which marketing activities are conceptualised.

Despite South Africa having a significantly lower Internet penetration level relative to Australia and Iran, the country's marketers appear to consider the Internet to have had a greater influence on most aspects of marketing practice. The evidence in the sample suggests that compared to Australian marketers in 2001, South African marketers in 2011 perceive the Internet to have had a statistically significant greater influence on 12 of the 31 items and on 16 of the 31 items in comparison to Iranian marketers in 2005.

Interestingly, in all three studies, marketers ranked the Internet's influence on communicating product/service information and improving the company's ability to keep customers informed as being the most significant. Similarly, marketers in the three studies all ranked the Internet's influence on influencing the way products are priced, eliminating less profitable segments and providing a way to price more accurately as the least significant.

\section{LIMITATIONS AND FUTURE RESEARCH}

In interpreting these results, it is important to take cognisance of the limitations of the study. First, a nonprobability sampling method was employed and, as such, caution should be exercised generalising the findings to the target population. Secondly, the study was cross-sectional in design. Continuous advances in Internet technologies and growth in Internet users and usage will continue to pose new challenges to marketers, making a longitudinal study more applicable to this type of study. For example, even though the Internet does not appear to be particularly useful for pricing products more accurately or eliminating less profitable segments at present, this may change and marketers need to keep abreast with these and other potential changes on a ongoing basis.

In addition to engaging in a longitudinal study, there is also scope in extending this research to include small and medium enterprise marketers' perceptions of how the Internet is influencing their marketing practices, with the view of uncovering ways in which they might take more advantage of Internet technologies.

\section{CONCLUSION}

Internet technologies have not only changed the environment within which marketers operate but have also provided them with tools that can enhance the execution of traditional marketing tasks. As advances in Internet technologies continue and the world becomes evermore connected, these technologies will continue to impact on the practice of marketing, bringing both opportunities and threats and necessitating that marketers stay vigilant to these changes.

\section{AUTHOR INFORMATION}

Kirsty-Lee Sharp is a full-time researcher in the School of Economic Sciences at North-West University (Vaal Triangle Campus). Her research interests include Internet marketing and mobile marketing. E-mail: klsharp21@live.com (Corresponding author)

Ayesha Lian Bevan-Dye is the research professor for the School of Economic Sciences at North-West University (Vaal Triangle Campus). Her research interests include Internet marketing, social network marketing and Generation Y consumer behaviour. E-mail: ayeshabevandye@gmail.com or Ayesha.Bevandye@nwu.ac.za

Natasha de Klerk is a senior lecturer in the School of Economic Sciences at North-West University (Vaal Triangle Campus). Her research interests include service marketing and fashion marketing. E-mail: Natash.deklerk@nwu.ac.za 


\section{REFERENCES}

1. Bevan-Dye, A.L. \& Venter, P.F. (2008). Rethinking marketing curricula in the Internet age. SAJHE, 22(3) 538-555.

2. $\quad$ Boateng, R., Heeks, R., Molla, A. \& Hinson, R. (2008). E-commerce and socio- economic development: conceptualising the link. Internet Research, 18(5) 562-594.

3. Eid, R. \& Trueman, M. (2002). The Internet: New international marketing issues. Management Research News, 25(12) 54-67.

4. Financial Mail. (2009). Financial Mail top companies 2009. Retrieved from: http://www.topcompanies.co.za

5. Florenthal, B. \& Shoham, A. (2010). Four-mode channel interactivity concept and channel perceptions. Journal of Service Marketing, 24(1) 29-41.

6. Ghazisaeedi, M., Pitt, L.F. \& Chaharsooghi, S.K. (2007). A conceptual model for Internet's impact on marketing in Iran. Direct Marketing: An International Journal, 1(3) 125-145.

7. Internet World Stats. (2012). World Internet Usage and Population Statistics: 31 December 2011. Mini Watts Marketing Group. Retrieved from: http://www.internetworldstats.com

8. Landberg, S. (2003). Strategic Marketing Technology. Best's Review, 104(6) 114.

9. Leong, E.K.F., Ewing, M.T. \& Pitt, L.F. (2003). Australian marketing manager's perceptions of the Internet: a quasi-longitudinal perspective. European Journal of Marketing, 37(3) 554-71.

10. Maake, M. (2012). Vast numbers of mobile users presenting big opportunities. Sunday Times, Business Times, 11 March 2012, p. 7.

11. Martin, L.M. \& Matlay, H. (2003). Innovative use of the Internet in established small firms: the impact of knowledge management and organizational learning in assessing new opportunities. Qualitative Market Research: An International Journal, 6(1) 18-26.

12. Masote, M. (2012). Tablet users hungry for data. Sunday Times, Business Times, 11 March 2012, p. 7.

13. Mawson, N. (2012). SA's Internet economy to double. ITWeb. Retrieved from: http://www.itweb.co.za

14. Morris, M.H., Marais, P. \& Weir, J. (1997). Is the Web worldwide? Marketing effects in an emerging market. Journal of Strategic Marketing, 5(4) 211-231.

15. Schiffman, L.G., Kanuk, L.L. \& Wisenblit, J. (2010). Consumer Behavior (10 ${ }^{\text {th }}$ ed.). Upper Saddle River, NJ: Pearson Prentice Hall.

16. Tubbs, B. (2012). Festive e-shopping SA's biggest yet. ITWEB. Retrieved from: http://www.itweb.co.za 